\title{
Geo-Political Dimensions of Brics: An Emergent Requirement of Strengthening New World Information Order in a Changing Global Landscape to Rebalance the Global Communication Order
}

Buddhi Prasad Sharma*

Institute of Communication Studies, Communication University of China, China

\begin{abstract}
BRICS is an alliance of five major economic countries Brazil, Russia, India, China and South Africa. All members of the BRICS have huge potential to become the dominant economies by the year 2050. These countries cover $30 \%$ of the world land coverage and around $40 \%$ of the world population. According to the report of the Goldman Sachs, these countries hold a combined GDP of \$25 trillion and are among the biggest and fastest growing emerging markets. Through political and economic cooperation, BRICS community tries to establish new global order based on mutual trust and harmony. Under the pressure of Non-aligned countries in the 1970's, UNESCO took historic decision to launch NWICO. Noble Peace Prize laureate and head of the UNESCO panel MacBride Commission Sean MacBride coined the term NWICO. The Commission recommended some important agenda to make global media representation more equitable. Its report titled "Many Voices, One World", which became the theoretical and philosophical basis for the NWICO. It aimed to end the information and media hegemony of the some powerful countries and establish the equitable, balance and social-representation based information and communication system. This trend worked until the mid of the 1990's, but again then dominant media paradigm overtake the information system. Now with rapidly changing global political and economic dimension, issues of the NWICO with new version again rise from different circles and angels. BRICS should use its strong platform, resource and capability to address growing public demands of the new version of NWICO. It is very sunshine that in the present digitalized media system era, old version of media principles and practices could no longer work. It is very relevant and natural to search and produce new information order, which can compactable to the present global communication demands and requisite. This research paper tries to analyze historic dimension of the NWICO and recommends some agendas to strengthen NWICO to rebalance the existing global information order. The study is based on qualitative research and description in nature. It studies the historical phenomena of the NWICO analyzing its strong and weakness while implementing the policies and suggests some pragmatic aspects to create new version of the NWICO according to the present changing landscape of the political, economic and social structure of the world. It is found that time is vital for launching new version of NWICO and BRICS nations should take this issue seriously and take pragmatic initiative.
\end{abstract}

Keywords: Brics; Nwico; MacBride Commission; Many Voices; One World; Dominant Model; Changing geo-political order; Rebalancing the Global Information Order

\section{Introduction}

With the changing global political, economic and social landscape, role and stand of the BRICS significantly increased. The term BRIC first time coined by Goldman Sach's economist Jim O'Neil. South Africa became member some later. Then BRIC changed into the BRICS. In his report O'Neil emphasized on that Brazil, Russia, India and China could bring new dimension in global economy in the new millennium. $\mathrm{He}$ also further suggested on including all BRICS members in to the G7 as their macroeconomic significance increased in the decade to come. From a worldwide investment viewpoint, the world has progressed on from there to a broader set of dynamic emerging countries, in Asia, Africa and Latin America too, to get their way to achieve dynamic growth and prosperity with minimizing internal structural challenges [1]. Though issues of sustainable growth and structural and political challenges are questioned on the BRICS arena, their influential roles to continue effort on addressing common world economic issues are also commendable. Scholar Anthony Van Agtmael wrote in foreign policy, "BRICS consumers are also beginning to rival their American counterparts in terms of total purchasing power. More cars, cell phones, televisions, refrigerators, and cognac are now sold in China alone than in the United States. Even with slower growth the economic engine of the BRICS should be more important than that of the United States or the European Union for most of $21^{\text {st }}$ century".
The issued documents emphasize on a major objective of BRICS community in a much contested scenario in the world geo-political and economic equation. The first summit of Russia highlighted on that this initiative is not against the West but to rebalance the world equation. In June 2009, a first leaders meeting was hosted by Russia in Yekaterinburg, bringing in Heads of State from Brazil, India and China. South Africa formally joined the group in 2010 on the invitation of China to participate in the Sanya BRIC Summit in China, following it the name BRIC replaced by BRICS. There have been multiple views to analyze the nature of BRICS. Some experts want to explain the activities of the BRICS to enlarge the present global system, which particularly created after the $2^{\text {nd }}$ World War specifically in the leadership of America. Since the inception of the BRICS to till now, there has been

*Corresponding author: Buddhi Prasad Sharma, Institute of Communication Studies, Communication University China, China, Tel: +86 106577 9145; E-mail: yesmanbush@gmail.com

Received July 27, 2018; Accepted September 17, 2018; Published September 24 2018

Citation: Sharma BP (2018) Geo-Political Dimensions of Brics: An Emergent Requirement of Strengthening New World Information Order in a Changing Global Landscape to Rebalance the Global Communication Order. J Mass Communicat Journalism 8: 390. doi: 10.4172/2165-7912.1000390

Copyright: () 2018 Sharma BP. This is an open-access article distributed under the terms of the Creative Commons Attribution License, which permits unrestricted use, distribution, and reproduction in any medium, provided the original author and source are credited. 
Citation: Sharma BP (2018) Geo-Political Dimensions of Brics: An Emergent Requirement of Strengthening New World Information Order in a Changing Global Landscape to Rebalance the Global Communication Order. J Mass Communicat Journalism 8: 390. doi: 10.4172/21657912.1000390

Page 2 of 7

much hard work by various experts to produce literature about it. They tries to put perspective and reasons on the establishment of BRICS community in the complex global scenario in terms of economic and security spheres [2-4].

According to the World Bank, by 2030, two-thirds of the global investment and saving will be in developing countries, including the BRICS in that section, compared with one-fifth in 2000 [5]. A data published by the Organization for Economic Co-operation and Development (OECD), China and India together will be larger than the whole OECD economy by 2025. It seems very clear that global order of after Second World War has been drastically changing with the dawn of the $21^{\text {st }}$ century with raising various countries in terms of economy and other global concerns. The structure of the BRICS summit process is to be seen as a part of scientific outlook with inclusive ways. Definitely no doubt that reform on the international financial and economic institutions and enhancing the multilateral and multi-polar world order are their major principle and basic guideline for foundation and promotion. As an active member of the BRICS community China has shown more attempt to promote BRICS's spirit in the multiple areas [5]. $5^{\text {th }}$ BRICS summit, which held in Durban city of South Africa in 2013, says in its declaration that institutions, which were conceived in circumstances when the international landscape in all its aspects was characterized by very different challenges and opportunities, regulate the prevailing global governance architecture. It later on made the objective of progressively developing the BRICS into a full-fledged mechanism of current and long-term coordination on a wide range of key issues of the world economy and politics. It is said that these objectives includes the establishment of a 'virtual secretariat' [6]. With the dawn of the $21^{\text {st }}$ century global system demands new configuration and patterns which is also genuine to address new challenges and reality of the world equation. In this context the problem of re-deigned of global governance in the $21^{\text {st }}$ century can hardly be sort out through old mechanism created by Congress of Vienna or a Versailles Treaty, or a San Francisco Conference or new Bretton Woods instruments. Accordingly, the present state of global system is not made of revolutionary process but also gradual process and efforts of many to create present order. Every BRICS summit has emphasized and declared for a new vision on new era to address the vital questions of the world. Some time, some goals of BRICS and G20 are also compatible but BRICS provides more inclusive and alternatives views and agendas for mostly inclusive and balance global order.

With the emergence of the BRICS, discussion on the new information and communication order is also come in the front. It is also because these are the same countries, which played important roles to bring out New World Information and Communication Order (NWICO) in the 1980s. Mostly developing and underdeveloped countries again looking toward BRICS for launching new revised pattern of the NWICO, which could mitigate the unnecessary propaganda of the Western communication and media instruments and provides the new pragmatic alternative. In the 1970s Non-Alignment Movement (NAM) and UNESCO both had played influential role to bring out NWICO. At the higher time of the cold war, while the information were dominated by US-led western front and also some aspects of information flew through USSR side, world people were really deprived to get factual and objective information about the happening of the world. Not only this even in the policy level, the two blocks: USA and USSR had given unnecessary pressure to the other sovereign nations to copy and implement their model blindly. In that information terrifying situation, countries of the NAM initiated global campaign to challenged dominant western information order and establish the new objective information order. Fortunately, in that movement majority numbers of the developing and under-developed countries had given support and finally UNESCO was obliged to take action for new world information order. Support and pressure of the civil society groups of the world and intellectual circles and also common people were commendable and instrumental.

In this paper researcher tries to analyze the past NWICO and focus to on the requirement of the new version of New World Information and Communication Order in the new world circumstance and context. Paper also emphasizes on that BRICS member should take the revision on the NWIC seriously to address the new requirement and tries to formulate new relevant visions of NWICO in the new global context.

\section{Methodology}

For the research, the fixed evidence reports were vital in the process of writing. Qualitative approach of the research is used for the study. Policy documents, media reports, interviews, magazines, social media feeds, conversations of head of states, party official documents, and the like were used extensively. The research has been divided into ten headlines and in all of them; there is one distinct feature that it solely tries to cover up the overall issues regarding with BRICS and NWICO. Due to the natures of the study, research writing and analysis is descriptive and elaborative.

\section{Brics and nwico: more common agendas than differences}

The MacBride Report, which was published in the 1980, highlighted the need for a New World Information and Communication Order (NWICO) and submitted the results of UNESCO's International Commission for the Study of Communication Problems that was set up in 1977 headed by Noble Peace Prize winner Sean MacBride [7] Launch of the NWICO raised the genuine issues in the world arena. Mostly America and its allies took the issue of NWICO against them and blamed it saying that it had blindly supported the agendas of the Soviet Union. From the beginning, American administration showed very negative posture for NWICO. It is also because NWICO talked for the new world information order, which aimed to change status quo of the information system. When US decided to leave UNESCO in 1983, it stated: "UNESCO has extraneously politicized virtually every subject it deals with, has exhibited hostility toward the basic institutions of a free society, especially a free market and a free press, and has demonstrated unrestrained budgetary expansion". This decision makes all wonder and create a lot dissatisfaction among it's allies too. The US Assistant Secretary of State for International Affairs J. Newell marked that UNESCO policies, for several years, have served anti-US political ends. Likewise, prominent American paper New York Times wrote that the Washington based Heritage Foundation has been criticizing the organization for about two years in reports and statements opposing that the United States had turned into a largely anti-American club dominated by the Soviet bloc, by European leftists, and by radical countries in the third world. This displayed the American intention on NWICO. Britain also followed the American way and left the UNESCO. Later Britain rejoined UNESCO in 1997 and America in 2003. The US and UK's role also resulted in the departure of the Director General of the UNESCO Amadou-Mahtar M'Bow: "NWICO was criticized as a curb on media freedom, whereas in actuality the idea was designed to widen and deepen the freedom of information by increasing its balance and diversity on a global scale. For its originators, NWICO was a committed instrument of diplomacy, and Third World dictators did not need it as excuse for suppressing media. The anti-NWICO campaign was an ideologically repentant exercise by private media 
Citation: Sharma BP (2018) Geo-Political Dimensions of Brics: An Emergent Requirement of Strengthening New World Information Order in a Changing Global Landscape to Rebalance the Global Communication Order. J Mass Communicat Journalism 8: 390. doi: 10.4172/21657912.1000390

Page 3 of 7

proprietors, and it became effective only because of the extraordinary power with which it was waged. In this sense it is justified to call the campaign a 'Big Lie"' [8]. Severely beaten monetarily by the US and UK departures, UNESCO as a consequence "not only abandoned the strategic direction of the South and East; it did its utmost to appeal to the West" [9]. Its report was criticized as diverse, giving in too much to liberal ideology, and abandoning how media and communications are entrenched into societal entirety and understanding the role of transnational corporations [10].

Though NWICO campaigned not much successful as expected, its principles and issues still are relevant. Since the beginning China, India, and Brazil vocally raised the relevancy of the new information order. After the thirty years, through the BRICS, relevancy of the new framework of the NWICO is expecting everywhere. Objectives of the BRICS are more similar with the visions of the NWICO. Both don't accept uni-polarity and encouraged multi-polarity. Both talked about the open objectives, equal-based and inclusive information flow. The most important thing is that time is ripped to revised the old NWICO and make it according to the present context and future-oriented.

Nordenstreng [9] specified that the "MacBride Report was indeed relatively lightweight," but supported fairly a lot of political encumbrance and came to indicate the global undertaking towards democracy and equity in communication encouraged on by the decolonization offensive of the early 1970s." NWICO within short span of time got succeeding to improvement large popularity. Even those who went against its principle also took its issues as historical phenomena. A pioneer researcher Armand Mattlelart [11] contended that its utmost quality is the fact that it existed. It was happened first time in the history of UN organization to issue formal document to balance communication system and eradicate the erroneous aspects of undertaking pervading in the field of information system. Stated clearly on that with NWICO, world media system had entered into a new path and many debates and questions it raised to reform existing media and information system.

Now what the BRICS outstretched issues of modern communication technology and system, thirty-five years ago NWICO accentuated on modern communication system. Now due to the rapid computing and globalization force, social and technological networking is highly increased and also become the very productive social forces, which could give pressure any stakeholders to design or implement any policies. In the changing world context at that time the MacBride Report clearly stated that a new era of communication is opening up. It is a now conceivable that a worldwide communication system could be built that world link any point of the planet with any other. Equally, no doubt that worldwide huge networks are linking up which ultimately conjugates all concerned communication segments [12].

BRICS countries knowing the present demands and requirement of the global citizen need to do immense work to issue common agendas for the new version of NWICO. Though major objectives of the previous NWICO are compactable with the BRICS spirit, in the new global situation, context and expectation of the large global citizen, need to revise old NWICO and issue the new version of the NWICO.

\section{Issues of communication inequalities in the global sphere}

MacBride Report is thoughtful document about the global information inequalities and disorder. Since the 1970s from various sections countries to intellectual circled raised the voices about existing information and communication flow system, which was predominantly American-inclined and highly discriminatory. MacBride Report inclined to postulate benefits from information and communication, a condition to which it had responded by demanding human rights to communication [12]. The Report fully concentrated on the issue of mitigating of freedom of equality in the context of the communications whereby it suggested breaking that barrier and opening the multiple doors of balance communication system. Criticism of the report include the political and commercial censorship of the media system, media convergence and concentration due to the unnecessary monopolizations of the few numbers of elites, dominant paradigm (top-down) approach which tends to exclude the value of opinion of the common citizen, using the very limited and unfair sources reducing the multiple sources etc.

The report of The MacBride Commission comprised 82 recommendations targeted at "eliminating imbalance and disparities in communication and its structures, and particularly in information flows". Actually that has aimed to enlarge and strengthening decentralized, public-based and common modality of the structure of communication system and media. The Report observed a NWICO that will be based on "international assistance and contributions towards international understanding" " and co-operation on a worldwide scale; open relations of interdependence and complementarities, based on mutual interest and equal dignity of nations and peoples and more free, more equal, more just relations whining all societies and among all nations and peoples."

Currently embryonic problem is still that capitalist model of communication and media system is internationally displaying hegemonic posture and overriding role that the neo-liberalization and commercialization of the all builds the endurance of publicly or commonly controlled media that dominated public service matter problematic $[13,14]$. In his prominent book "Postcolonial Theory and the Specter of Capital" the sociologist Vivek Chibber argued: "As capitalism spreads across the globe, it does not inevitably turn every culture into a replica of what has been observed in the West. The universalization of capital is perfectly compatible with the persistence of social cultural and political differentiation between East and West. Capital does not have to obliterate social difference in order to universalize itself. It merely has to subordinate those dimensions of social reproduction and that are essential to its own functioning. These dimensions are the ones directly involved in the production and distribution of use-values. Capitalism can sustain a broad gamut of power relations and social identities" [15].

Though with the dawn of the $21^{\text {st }}$ Century in the political, economic, technological and cultural realms there have been massive changes globally. Even though communication and information inequality is still prevailed, the fight for social justice is continue. Present age is digital age. It in one hand success to give vast access for sharing perspectives but in other hand due to the upmost implementation of the neo-liberal methods digital inequality is also vastly increased. It includes like unequal access to media technologies, unequal distribution of digital knowledge, unequal benefits using the digital technologies etc. According to the Millennium Development Goals 2014, statistical annex, although Internet access in the developing and under-developing countries largely increased in the last decades, many difficulties and challenges prevail ahead. India and China improving relationship in the political and economic fronts could also contribute to harness prosperity and resolve many structural problems in both countries [16]. Even now so many under-developed countries are facing problem in the quality technologies. Mostly elites and socially privileges 
Citation: Sharma BP (2018) Geo-Political Dimensions of Brics: An Emergent Requirement of Strengthening New World Information Order in a Changing Global Landscape to Rebalance the Global Communication Order. J Mass Communicat Journalism 8: 390. doi: 10.4172/21657912.1000390

Page 4 of 7

groups have got more benefits. Aids of the developed countries to the developing and underdeveloped countries are unfortunately draconian condition-based. It means there is already biasness to use the technologies. Elites try to misuse the media technologies to serve their class-interest and also try to reduce the voices of the common people. These kind of physical and physiological gaps are not decreasing in the present new global context but even increasing. It is said that given socio-economic, political and cultural inequalities in the world, urban elite, educated and relatively rich people are mostly benefited but other lower-faction in terms of above basis are excluded systematically.

No doubt that until the existence of the full-scale capitalism, various forms of inequalities exists in multiple spheres of communication technology to the use of it. According to the Forbes data source, among the hundred largest companies of the world seven companies are from telecommunication sectors and hold by capitalist entrepreneurs, also shows that access to the communication technologies are high for the capitalist and elites groups and rest are obliged to gain technologies and communication flow by the capitalist groups. Time is ripe for searching the alternative paradigm compactable for the new global context. That alternative will try to address the present digital inequalities and give genuine space for the common people who are still now obliged to grab western dominant information system. No doubt that alternative ways are retain in the objectives of the MacBride reports. Only thing is that BRICS as a strong platform of emerging powers should start discussion seriously on the global demands of the equal communication access and against the top to bottom model of the communication.

BRICS has capability, power, strength and resource to alter the global information order. The reason behind the eyes watching to it form the rest of the world is also its strengthens to give alternative order which can balance the present highly unequal order. For that, pressure from the scholars, academician, civil societies groups and public spheres also essential. It is also because that situation makes realization to the BRICS members to start in time and shows some effectiveness respecting the genuine voices of the pubic spheres.

\section{Rising brics and compelling demands of new version of nwico}

China is taking massive stake in the global arena with its peaceful rise policy. As a second economy in the world, it has been multiple impact and influence in the global economic sphere and system $[17,18]$. Now China has the largest foreign-currency reserve with around $\$ 4$ trillion dollar in 2016. In 2014, China has surpassed USA in terms of purchasing power parity, making it the world's strong economy according to the International Monetary Fund (IMF). As one influential commentator wrote that no longer is China an emerging great power, it is a 'risen' one [19]. It is said China's peaceful development policy success to send positive message of cooperation. Generally in the developing world, followers of China's economic success are many; it is also inspired them on stimulating dialogue of superseding the "Washington Consensus"). Trade volume between China and Africa since 2000 have grown 30 fold, reaching $\$ 200$ billion dollar in 2012. China also has replaced the America as the biggest trader in Africa. Though border dispute are remain to resolve ChinaIndia trade relations are in the historical phase. Both countries have expected to cross $\$ 100$ billion dollar trade volume by 2019. Due to the American and European economic embargo against the Russian, she turned toward China for historic economic cooperation. In 2014, China and Russia signed world's biggest oil and gas deal volume of $\$ 400$ billion. According to the deal, Russia will provide 38 billion cubic meters of natural gas per year for 30 years-shows the emerging SinoRussian relations in the new global context. It also shows the changing dynamism of the world order and entering the world in the multi-polar spheres. This economic dynamism has told the increasing strength of the BRICS countries in the global arena. Similarly, most of the scholars who are watching growing development in the BRICS agree on that due to the realist growth of the BRICS, an emergent requirement of the new version of the NWICO is imminent and BRICS are able to profound and implement.

Domestic media growth in the BRICS countries is also high though media business is decreasing in USA and many European countries. According to the World Association of the Newspapers and News Publishes, the circulation of daily newspaper has continued to demonstrate growth in Asia of more than six percent during the period of 2009-2013; it was a time while media business in North America and Europe faced critical economic crisis and decline. With the growth of media industry in the BRICS, it contributed on the rise of the advertising revenue and helps to aggravate the market economy.

Since the beginning NWICO raised the issues of the imbalance in the global news-flow. Some big media of the Global South has been distorting news on the favor of their specific interest ignoring the real voice of the rest of the world. News agencies like Associated Press, Reuters, Agence France Press and United Press International; newspapers: The New York Times, The Washington Post, Wall Street Journal, Times etc, Television: CNN, BBC, ABC, Fox News etc, these western media has been systematically distorting the international news flow and providing very biased and non-objectives news and views about the rest of the world. In the era of digital technology, with the changing political-economic dimension, global media dimension also changed and in the new situation it offers new challenges and opportunities for previously marginalized voices need to be addressed [20]. Since the dawn of the $21^{\text {st }}$ century, some changing media landscapes also occur, and doing effort to mitigate influence of the western media. Russia's RT, Al Jazeera of Qatar, China's Global Times and CGTN etc. are those media, which are taking space and trying immense to balance the global media equation. Al Jazeera English is taking huge space and representing the many voices. Since it's beginning in 2006, it has taken bold steps in the international news flow and also contributes to address the "many voices" in global communication arena. Media expert Subhash Dhulia [14] opined that because of the changing political and economic scenario in the world, more discussion have come in the front to tackle non-balanced information system.

Examples of the Al Jazeera, RT and CGTN shows that if some more efforts happened, "many voices" could be address and global communication spheres could be more balanced than before. In this present vital globalization and digital ages, where large portion of the people of the world have Internet access, it is increasing too, still dominant media voices of the West could not be acceptable and appropriate. Members of the BRICS and its other partners should take this issue seriously. Information and communication order is significant issue. It is also ways to retain recognition of the own agendas. Why did America and some portions of the European countries success to maintain their ideological and developmental agendas? It is their long time control in the international information and communication order. But NWICO is not that which aimed to reduce and Western information flow and increase the other portions media order, but it aimed to create an environment in the global arena in which all voices could be heard and address through information and communication system. This situation will be more balance, objective, accurate and more representative than the previous biased and discriminatory dominant model. BRICS nations should put the 
Citation: Sharma BP (2018) Geo-Political Dimensions of Brics: An Emergent Requirement of Strengthening New World Information Order in a Changing Global Landscape to Rebalance the Global Communication Order. J Mass Communicat Journalism 8: 390. doi: 10.4172/21657912.1000390

Page 5 of 7

agenda of new version of the NWICO in their vital summit and should success to issue a new declaration on it. If they did that, new debates and even practice will be started and tangible changes also occur. This is also because now Western media are facing historical challenges not only from the economic perspective but also grand trust deficit. They are facing an acute blaming of Fake News.

\section{New era and new information oder}

It is also natural that though emerging powers came in the front of the international power equation, existing power doesn't want to compromise easily. It starts to play various roles to retain power. Some sections of the experts also don't want to give more emphasizes to the alternative forces in the beginning. There is no doubt on the issue of the American decline with dawn of the $21^{\text {st }}$ century, influential commentators such as Fareed argued that United Sates will remain "pivotal power in international politics for a long time because there is " still a strong market for American power, for both geo-political and economic reasons. But even more centrally, there remains a strong ideological demand for it" [21]. But in the other sections of the experts stated that although United States remain the major power in the global arena, it has no other alternatives to recognize emerging powers and sharing the global governance [22]. During the past two decades there have been massive changes in the non-Western nations in the media sectors too.

With the relative decline of the West, mostly BRICS countries got huge opportunity to aggravate their strength in various spheres. Actually, decline of the West provided opportunity for BRICS to participate and play constructive role in the global governance system, which predominantly occupied by US-led parochial alliance $[19,23]$. Human Development Reports since 2013, published by UNDP, also forecasts that by 2020 combined economic volume of Brazil, India and China will be high than the combined production of the US, UK, France, Germany and Italy [24]. It also gave the clear message that so-called US dominance is declining in its historical ways and new alternative emerging in the full-fledged. Non-Aligned Movement (NAM), which still in working though not actively, succeeds to give pressure to the UNESCO to take bold initiative [25].

Like the changing political and economic order, it naturally demands the new global structure and institutions. Birth of the NWICO also came at a vital time of changing global power politics. The profounder of the NWICO agreed on that problem in information order creates global inequality and biasness; it ultimately suffered the poor people of the global south. Information system has multiple impacts on social, economic and cultural aspects of the people. On course of campaigning for a balanced communication and information order, non-governmental organizations (NGOs) have also played significant role to give pressure on Western governments [26]. Nonwestern people always opine views for balance information system. In the 1970s and 1980s due to the ideological confrontation between American and Soviet bloc gave more pressure for the rest of the world to take action; but now developing world are in a position to deliver in practical. Knowing that situation Mustapha Masmoudi, former Tunisian Information minister, who was also member of the MacBride Commission, opined that owing to the socio-technological imbalance there was a one-way flow of information from the "center" to the "periphery", which created a wide gap between the "haves" and the "have not's",

The information rich were in a position to dictate terms to the information poor, thus creating a structure of dependency with widespread economic, political and social ramifications for the poor societies;

This vertical inflow (as opposed to a desirable horizontal flow of global information) was dominated by the Western-based transnational corporations; information was treated by the transnational media as a "commodity" and subjected to the rules of the market.

The entire information and communication order was a part of and in turn propped up international inequality that created and sustained mechanisms of neo-colonialism [27].

What emphasized Masmoudi did are still relevant and will be good reference for the BRICS nations to learn from history and start the new initiation. It is also time to evaluate the why principles of the NWICO were not implemented for a long time though their aimed were highly appreciated by many countries and large number of population of the world. BRICS nations are now in conditions to show their maturity in leading the global information order. China and India now have experienced huge amount of media growth. Media in these countries are strong on all aspects from reporting to presentation through modern communication system. Western media has also given more attention on the summit of the BRICS and happening in the BRICS countries. It is because present global governance system could not go alone only taking agendas of the Western blocs. There are a lot of changes in theory and practices in the media system since two decades to till now. If these aspects are not understood and again try to push up old dominant order, definitely it will not success and faced severe criticism. Some media critics also opined that like the present political and economic paradigm of the world, media system is also in a transition. President of BRICS New Developemnt Bank (NDB) says that BRICS efforts could create tangible environment to play more active role by the BRICS community in the global economic arena. This transition period is definitely significant to launch new order. All members of the BRICS should take efforts to establish new global information order. Changing time naturally demands change in the existing order. Retaining present communication order could not give justice to the world citizen. It is not only the issues of the BRICS members but also agendas and demands of the billion people of the world. Who are for long time compelled to gain western-dominant information, which are highly distorted from facts and based on the model of top to bottom. Genuinely, vertical or dominant model cannot address the information and communication requirements of the global citizen. BRICS members need to take this vital opportunity to launch and execute new global information and communication order, which would success to rebalance the present statues of the global information order.

\section{Challenges and Prospects}

No power wants to leave easily their existing position though they are threatening by other powerful forces. While NWICO came in front, America and its allies thought that it would historically reduce their dominant voices. So they did a lot to hamper the flow and expansion of the NWICO. With the collapse of the Soviet Union in 1989, America became sole superpower of the world. Again with hyper pompous it started to forcefully implement "Washington Consensus" in the rest of the world. No American affairs experts thought that pompous will be decimated or reduced sharply within one and half decades. With the dawn of the $21^{\text {st }}$ century, America and its allies felt that multiple forces and world challenge their strength and power is already enter into the multi-polar world. The BRICS community has lost some opportunities while they some members of the BRICS faced acute economic and 
Citation: Sharma BP (2018) Geo-Political Dimensions of Brics: An Emergent Requirement of Strengthening New World Information Order in a Changing Global Landscape to Rebalance the Global Communication Order. J Mass Communicat Journalism 8: 390. doi: 10.4172/21657912.1000390

Page 6 of 7

political problems. As Liu [28] stated: 'The economies of the China and India have contributed to perform well, but Brazil and South Africa are grappling with economic crises, and low commodity and oil pricesmaking it difficult for them to contribute to the bloc.' There are the large voices of China, Russia, India, Brazil and other developing countries. American blocs realized that there are no other alternatives to accept the changing geo-political, geo-economic and geo-strategic dimension of the world. Chines President Jinping [29] said that incessant conflicts in some parts of the world and hotspot issues are posing challenges to world peace. US always tries to play game creating the instability in several countries. Though there have been strong demands from the world people side and also BRICS nations have strength, it is also not an easy task to go differently. It is assumed that there are some challenges in road of BRICS to launch and execute the new version of NWICO. This researcher sum up these challenges as follows:

BRICS still lacks in-depth discussion on the issue of the new information and communication order.

They have not acknowledged necessarily the significance of new version of the NWICO in the changing global context.

BRICS members still have lack of maintaining common voice on the common issue regarding with glow information order.

Transitional phase of the world scenario since the 2008 economic crisis still has impact on the global affairs.

BRICS nations still not showing themselves alternative of the existing global order though large numbers of the people of the world expected from them.

Lack of coordination and consensus building on the vital issue of global communication order.

Even though there are vital challenges before the BRICS to launch new version of the NWICO, prospects of the starting new waves also prevails. These emerging economics are also itself new voice. Changing political and economic landscape requires the new information and communication order to rebalance the global situation. "Washington Consensus" is already failed. It created more problems and supported for various conflicts and also played role to divide the segments of the world. "Washington Consensus", it is sunshine clear that could not serve for the world peace, stability and equality. In terms of global information and communication perspective, it is hugely biased and discriminatory concept. It never talks about inclusive voice of the global citizens, only talked about the interest of the American allies. In his scenario, a prospect for new version of the NWICO is inevitable. BRICS as a representative of the large portion of the citizen of the world should take initiative as soon as fast. With rising people's consciousness, modern communication technologies and influence of the social media there are no other alternative to change present Western dominant communication order. BRICS nations should grab prevailing opportunity to change existing discriminatory global information and communication order.

\section{Conclusion}

In the course of the new NWICO, a tangible and pragmatic effort is necessary to make structure and process of new international information and communication order. It is also true that existing center don't want to leave its space easily. If some pressure occurs from somewhere, they use different strategies to maintain their hegemonic posture. So now the question is qualitative and quantitative changes in the information system and flows. Qualitative transformation in the contents, issues and agenda could give alternative space and tackle the problem created by dominant information order of the Western allies. Similarly, Quantitative transformation in technological changes and news flow could bring tangible changes on half of the periphery spheres. Advertising business, circulation, listeners and viewers of the Western media are dramatically decreased. According to some research, there is increasing trust deficit about Western media not only in the citizen of the non-western countries but also in the Western people too. It is said that negativism and biasness even increase in the Western media than before. "Fake News" popular term of American President Donald Trump, also emerges issue of objectivity, accuracy and balance in the Western media circles.

In the course of this study, the researcher read many documents and writing materials related with BRICS. The most important factor, which I found among the writing of the most of the academicians and scholars that they are more optimistic and hopeful for the BRICS's growing strength and future. Now BRICS countries have more stakes in international arena. UN system to international financial organizations and countries wise presence to policy implementation and coordination BRICS performance are highly acknowledged. Their collective voices on the issues such as financial situation, trade, intellectual property rights, cyber security, energy, climate change and others related issues have been taking strong stand and support. Respecting the sovereignty and integrity of the other nations and supporting to each other on genuine issues also make BRICS more inclusive and dynamic. Due to the exposition of the BRICS nations, the term Global South is highly used and mentioned in many intellectual debates and forums. BRICS nations could not deceive the growing expectation of the world citizens. NWICO was one huge effort to establish balance order. Now BRICS nations have responsibility to revise theme of NWICO according to the present political and economic dimensions of the world and assure people on that they are kindly working to establish balance information system, which will be free from biasness and discriminations.

BRICS alliance in the context of the historical process is in a strong condition but also surrounded with many questions. Due to the lack of internal power and strong cooperation Non-Aligned movement did not achieve its goals. Non-Aligned countries were in very weak position at that vital period of the cold war to give pressure to the capitalist and socialist blocks and bring the harmonious environment in the global affairs. But situation is different now. BRICS nations are emerging powers in terms of economy, technology, development, military and other various aspects. Their even single voice takes huge meaning. It could move forward giving tangible alternative of the Bretton Woods architecture due to their strength and power in the global economy. The goal of the Non-Aligned countries also was to give alternative ways in the global order but lack of the concrete cooperation and own strengthen it failed to achieve. BRICS shows possibilities to establish non-biased and balance order in the existing context. The road is not easy. It is definitely hard task to challenge powerful media conglomerate of the Western block. BRICS nations have already outlined to guarantee Internet access, in the alternative of the US dominant in the network Present Internet system's center is in the US and Europe. BRICS project on the internet system is called BRICS Cable, which expects to create an alternative route on world internet system preliminary rounds interoceanic system of fiber-optic cables of 34 thousands. It will have primarily capacity of the 12.8 terabits per second. It covers almost all territory areas of world and also aims to end the US hegemony in the world Internet communication access system.

Now the issue is how much BRICS nations are serious to give 
Citation: Sharma BP (2018) Geo-Political Dimensions of Brics: An Emergent Requirement of Strengthening New World Information Order in a Changing Global Landscape to Rebalance the Global Communication Order. J Mass Communicat Journalism 8: 390. doi: 10.4172/21657912.1000390

alternative of the existing information and communication order. Taking lesson from the Non-Aligned movement and implementation of the NWICO, BRICS nations should systematically cooperate and word hard to give pragmatic alternative of the existing dominant model. Still BRICS community has not gone with fast ways. Conceptually and in terms of the application, they still need to do hard work. Expectation of the world citizen from them is to take pragmatic initiative to end existing unequal world and grab opportunities for the development of prosperous, justifiable and equitable world order to address the great majority world citizen. It is said that to end the existing unequal and US hegemonic order, BRICS nations have now capabilities and also in course of the giving alternative they should also try to build mutual consensus with US too. Now time is ripping to launch new version of the NWICO rebalance to world information and communication order. How much BRICS nations would success it depend their future activism and conscious efforts.

\section{References}

1. O'Neil J (2001) Building Better Global Economic BRICS. Global Economics.

2. Oliver S (2018) Temer's Final BRICS Summit Is a Golden Opportunity for Brazil. America Quarterly.

3. Carmody P (2013) The Rise of the BRICS in Africa: The Geopolitics of SouthSouth Relations. London: Zed Books.

4. Sharma PB (2017) Pragmatic Approach on Inclusive Economic Governance. China Daily.

5. World Bank (2013) Capital for the Future: Saving and Investment it an independent World. Washington DC: International Bank for Reconstruction and Development and The World Bank.

6. BRICS (2013) BRICS Fifth Summit Declaration and Action Plan

7. Nordenstreng, Kaarle (2015) "A Milestone in the Great Media Debate". Quaderns del CA 21: 45-48

8. Nordestreng K (2013) "How the New World Oder and Imperialism Challenges Media Studies." Tripple C: Communication, Capitalism \& Critique 11: 348-358.

9. Mansell R, Nordenstreng K (2005) "Great Media and Communication Debates: WSIS and the MacBride Report." Information Technologies and International Development 3: 15-36.

10. Hamelink CJ (1980) Communication in the Eighties: A Reader on the "MacBride Report." Rome, IDOC International.
11. Mattelart Armand (2005) "The Stammering Discovery of the Processes of Internationalization." Quaderns del CAC 21: 53-54

12. MacBride Commission (1980) Many Voices, One World: Toward a New, More Just, and More Efficient World Information and Communication Order. Repor of the International Commission for the Study of Communication Problems. Abridged ed. London: UNESCO.

13. Williams Raymond (1974) Television Technology and cultural form. London and New York.

14. Dhulia Subhash (2008) The Great Debate of New World Information and Communication Order (NWICO).

15. Chibber V (2013) Postcolonial Theories and the Specter of Capital. London: Verso.

16. Prasad Sharma B (2018) Sino-Indo Relationship to enter new era of Cooperation. China Daily.

17. Daniel B (2015) The China Model: Political Meritocracy and the Limits of Democracy. Princeton University Press.

18. Raj DM, Vreeland JM (2014) What the New Bank of BRICS is all about. Monkey Cage.

19. Christopher L (2012) "This Time it's Real: The End of Unipolarity and the PaxAmericana." International Studies Quarterly 56 : 203-213.

20. Manuel C (2009) Communication Power. Oxford: Oxford University Press.

21. Fareed Z (2008) The Post-American World. London: Allen Lane.

22. Amitav A (2014) The End of American World Order. Cambridge: Polity.

23. Amrita N (2010) News Powers: How to Become One and How to Manage Them. London: Hurst.

24. UNDP (2013) The Rise of the South: The 2013 Human Development Report New York: United Nations Development Program.

25. Claudia P (2015) New World Information and Communication Order (NWICO).

26. Carrie B (2015) Revisiting the UNESCO Debate on a New World Information and Communication Order: Has the NWICO been achieved by other means?

27. Mustapha M (1979) "The New World Information Oder". Journal of Communication 29: 172-185

28. Liu Z (2017) Building a Bigger, Better BRICS wall against the West's global Order. BRICS.

29. Xi Jinping (2017) Xi Jinping Says a Dark Shadow Looms over the World after years of Peace. The guardian. 